\title{
Research on International Introduction and Promotion of Guangxi Folk Eco tourism Festivals
}

\author{
Lizhen Wei \\ College of Foreign Studies \\ Guilin University of Electronic Technology \\ Guilin, China
}

\author{
Ya Wang \\ College of Foreign Studies \\ Guilin University of Electronic Technology \\ Guilin, China
}

\author{
Ruiyun Zeng* \\ College of Foreign Studies \\ Guilin University of Electronic Technology \\ Guilin, China \\ Corresponding author
}

\begin{abstract}
The international promotion and introduction of Guangxi folk eco-tourism festivals is still in the initial stage of development. Its tourists' source market is mainly concentrated on surrounding cities or townships, and international promotion and introduction need to be strengthened. In view of this situation, the paper probes into the development status of Guangxi folk eco-tourism festivals. This paper discusses its current situation of international promotion and introduction, studying the strategies and methods of international promotion and introduction. Finally, this paper conducts an in-depth analysis of the role of Guangxi folk eco-tourism festivals in accelerating the economic development of Guangxi, stimulating the prosperity of folk culture and promoting friendly exchanges between China and foreign countries.
\end{abstract}

Keywords-Guangxi folk eco-tourism festivals; international introduction; promotion strategy

\section{INTRODUCTION}

With economic global integration, eco-tourism has become an internationally recognized "trend" [1]. Guangxi, as a province with 11 minority groups and beautiful landscapes in southern China, have been endeavored to rapidly promote the development of regional eco-tourism economy, with the aim to fully utilize its regional resources and inherit and develop its rich folk culture, and It involves the concept of Guangxi folk eco-tourism festivals, which is the social activities of folk culture combined with eco-tourism festivals. Based on ecotourism and folk culture, this paper deeply analyzes its development status and existing problems in politics, economy and culture, expounds the current status of Guangxi folk ecotourism festivals, and promotes the international promotion of the entire folk eco-tourism festivals by spreading the deep folk culture in Guangxi. And finally attracting more international friends to understand and support the development of Guangxi folk eco-tourism festivals.

\section{Present Problems of GuANGXI FolK Eco-Tourism FESTIVALS}

As a beautiful minority country with unique folk culture, Guangxi has not been well utilized and promoted due to the influence of its natural environment and infrastructure. The international promotion and introduction of Guangxi folk ecotourism festivals are still in the initial stage of development. Although Guangxi has gotten good results in the development of folk tourism, its promotion scope is limited to the surrounding areas. Xi Yubin[2] summarized his research on the 7th Guilin Gongcheng Peach Blossom Festivals and found that the tourists from Gongcheng Peach Blossom Festivals mainly came from Guilin and surrounding cities. The geographical concentration index of the tourist source market was 70.37, and the tourists were gathered in the same place. According to its tourist source market concentration index and the promoted objects, it can be seen that such festivals are difficult to attract tourists from other provinces, let alone foreign tourists. It is still necessary to make long-term efforts to promote the popularity of Guangxi tourism in the world. At present, the development status of Guangxi folk eco-tourism festivals is mainly as follows:

\section{A. Insufficient government policy support}

The in-depth development of Guangxi folk eco-tourism festivals requires the support of government policies. Government relevant departments of Guangxi Zhuang Autonomous Region pay more attention to folk eco-tourism. They actively encourage regions to attract investment, focusing on the development and utilization of ecological resources based on the principle of environmental protection and sustainable development, and strengthen the propaganda of folk culture. However, in many places, especially for some remote and backward areas, the government's attention to folk eco-tourism is not strong enough to make it fully developed. But with the development of social economy, these areas will be correspondingly improved. 
For example, in the first Gongcheng Moon Persimmon Festivals, the Gongcheng county government took relevant measures to promote the international sales of Gongcheng Persimmon, expand its popularity, and improve its economic level. He Qiu[3] mentioned the following: It is funded by the county government. From the second session, it will be held in the form of market operation. The organizer is the county government, and the organizer will determine the bidding method. It can be seen that this form of development of Gongcheng ecological agriculture and new rural construction has largely encouraged and guided the development of folk eco-tourism festivals.

\section{B. Weak economic base}

Economically speaking, most of the festivals origins are located in relatively remote towns and villages. Most of them rely on agricultural production and the international sales of agricultural and sideline products. The economic level in the region is relatively low. Although there will be many tourists coming and going during the holidays, which will drive the local economic operation, it will not promote the development of regional folk eco-tourism festivals well, nor will it promote the festivals propaganda better. Therefore, it is impossible to attract investment on this basis and promote economic development.

Taking Gongcheng Moon Persimmon Festivals as an example, it is located at Hongyan, a small village in Gongcheng Guilin. It is understood that Hongyan Village has planted million acres of persimmon, which can be sold to the harvest season, but the local residents only sell persimmons to street vendors or fruit wholesale markets that do not develop their own unique industrial chain or agricultural product brands. So the sales of persimmons during the non-festivals period were not satisfactory. Theoretically, the Gongcheng Moon Persimmon Festivals promotes the sales of persimmons. With the development of the Gongcheng Moon Persimmon Festivals in recent years, it has indeed attracted many tourists and promoted the local economic operation, but it has not yet formed a good economic system. Therefore, although Gongcheng has planted million acres of persimmon, many local people still choose to go out to work because the regional economic development is not very well.

\section{Traffic restrictions and incompetent infrastructure}

There are many steep mountains and little land in Guangxi. Even some areas have not yet been constructed completely. The origins of these festivals are mostly located in relatively remote towns and villages, even in remote mountainous areas. The road conditions in the villages are extremely poor. The location and transportation of the origin of the festivals will directly affect the development value of tourism resources, while the poor accessibility of most remote areas will have a great impact on the number of local customers. These inadequate infrastructures will directly affect the development and utilization of tourism resources [4].

For example, the first Yaogao Zhouli Cultural Tourism Festivals was held in a small mountain village at the border of Liuzhou city and Guizhou province in the northwest of China's Guangxi Zhuang Autonomous Region. It is located at the
Motianling mountains above an average altitude of 1,300 meters, so the infrastructure such as traffic, road conditions and road signs are incomplete. Because of this, it takes at least 7 hours for visitors to travel from the Liuzhou expressway to the site. The mountain road is rugged, the terrain is blocked, and the traffic is extremely inconvenient. So it is difficult for tourists to find this place. In addition, there is another big problem that lacking accommodation facilities such as accommodation, catering, entertainment, etc. Although tourist can experience the original Miao village life, this has directly led to tourists staying in Zhou Litun for short time and low tourism consumption. It must be mentioned that this kind of traffic "bottleneck" has also seriously affected the international contacts and exchanges of local residents, and the transportation of agricultural products in the village is also a great problem. The agricultural products cannot be transported, and the villagers naturally have no high economic resources. It also makes this beautiful small village developed slowly.

\section{Suggestions ON The INTERNATIONAL Promotion AND INTRODUCTION STRATEGY}

In order to better promote and introduce Guangxi folk ecotourism festivals, the author has visited some folk eco-tourism festivals such as Zhou Li Cultural Tourism Festivals, Gongcheng Moon Persimmon Festivals, Gongcheng Peach Blossom Festivals, Yangshuo Fishing Fire Festivals, etc. After understanding the specific conditions of the local festivals, the following discussion was held on the international promotion and introduction strategy of Guangxi folk eco-tourism festivals:

\section{A. Support from governments of all levels}

The government and local departments should vigorously support the international promotion and introduction of the Guangxi folk eco-tourism festivals, and provide policy support, financial support and talent transfer for the promotion work. Formulating relevant policies to protect the development of rural tourism, protecting the folk culture of ethnic minority areas, and especially letting local residents realize the preciousness of folk culture. We will guarantee the funding needs in the development of folk eco-tourism festivals,, so that they can boldly develop and keep making progress, actively encourage local youth entrepreneurs, make good use of the advantages of agricultural and sideline products, develop foreign e-commerce, promote the promotion and introduction of agricultural and sideline products in Guangxi, and help the region take targeted measures to help people lift themselves out of poverty. The government should also send excellent management talents to the village. In addition to excellent university student village officials, the government can also promote talent cooperation between universities and villages, strengthen ideological and moral culture education in rural areas, and guide regional folk culture and economic construction to realize rural areas revitalization. The government should guide the media to do a good job in followup work on rural development. Tracking and reporting on the government's official website, domestic and foreign social media platforms to help the village do a good job in publicity. And actively promoting it to protect the folk culture and attract 
more. At the same time, attract more volunteers or non-profit organizations to assist in the construction of "new villages".

\section{B. College students'participation}

The foreign language teaching departments of colleges and universities in Guangxi should also guide and encourage college students to actively participate in the promotion and introduction of tourism in Guangxi, carry out related topics, accurately translate the content related to folk culture with ethnic characteristics, and support college students to independently shoot bilingual documentaries that related to folk eco-tourism festivals, "micro-movies", or English translation creation travel brochure:

\section{1) Shooting bilingual documentaries}

Colleges and universities should encourage students to shoot bilingual documentaries and "micro-movies" about Guangxi folk eco-tourism festivals. Let the students record the folk customs and ecological sightseeing in the eyes and carry out translation, accompanied by a vivid and interesting English language, so that international friends can stay at home to feel the magnificent scenery and strong customs of Guangxi. Xi Yubin[5] made a large number of questionnaires on the 7th Guilin Gongcheng Peach Blossom Festivals. It is concluded that compared with $51.1 \%$ of the tourists who knew the Peach Blossom Festivals through the introduction of acquaintances. The number of people who know the Peach Blossom Festivals on the Internet only accounts for $15.6 \%$ [6]. Then, in this everchanging digital age, an increasing number of tourist areas have gradually developed the official website of tourism, and have their own tourism propaganda film, which also shows us that the "micro-age" represented by "micro-movie" has arrived[7]. At the same time, to promote the characteristic folk culture of Guangxi by means of filming records, it can attract the interest of international friends. Then leading them to participate in this folk activity, to explore the connotation of Guangxi folk eco-tourism festivals, and thus promote the development of Guangxi folk eco-tourism festivals' international promotion and introduction.

\section{2) Creating a bilingual brochure}

At present, most of the tourism festivals in Guangxi with good prospects have made great efforts in bilingual brochures. Universities should engage in more similar topics, so that students can understand and promote some of the lesser-known folk eco-tourism festivals, and help the development of Guangxi folk eco-tourism festivals. However, the ethnic minority localities of Guangxi folk eco-tourism festivals are more obvious. It is difficult to accurately translate local specific nouns in the translation process. In the international language barriers for these festivals, students should study the unique terms of minority areas and collect relevant materials. And contact the English translation experts who study folk. With their help, the translation language should be as accurate and appropriate as possible, and actively eliminate the language barriers that foreign tourists will encounter when they understand the festivals.

In general, universities in Guangxi should encourage students to actively promote folk tourism in Guangxi to international friends. Allowing students to improve their foreign language level, they can also let them experience Guangxi scenery and understand Guangxi humanities in a deeper level, and strive to become a group of English translation talents who are trained in Guangxi and understand Guangxi and love Guangxi. At the same time, colleges and universities should actively promote the culture of Guangxi to foreign students, organize or introduce foreign students to join Guangxi tourism as much as possible, and lead them to experience the colorful folk customs and appreciate the great scenery of Guangxi.

\section{Localities' construction of tourism services}

Perfecting the infrastructure construction of rural tourism services to gain the goodwill of tourists is a key step in realizing and building a rural holiday tourist area.

\section{1) Improving the infrastructure}

In the tourist attractions, the information provided on the scenic spots should also be bilingual. Characteristic road signs, attractions, local flavors, folk culture, tourist souvenirs are also translated into English as much as possible, so that foreign tourists can better understand and integrate into the local cultural atmosphere. In addition, for some villages that are remote and have no accurate navigation route on the navigation software, a large guide sign should be set on the roadside. Each road should also set up a signpost to guide tourists. If the person in charge of a remote mountain area can obtain support from relevant local personnel, you can contact the map software system to map local roads and attractions, and improve the local navigation map.

If the village promotes "original eco-tourism" too much, it will result in low tourist experience, short stay time and low consumption level. Local governments should encourage local villagers to develop farmhouse tourism, promote the development of tourism services such as catering and accommodation, and explore local special entertainment activities, thus creating a local national festivals cultural brand, combining economics and culture to stimulate the prosperity of folk culture and regional economic development.

\section{2) Improving the entity travel service site}

Set up tourist service stations beside bus stations, highspeed railway stations and airports to provide bilingual information services for relevant Festivals tourist sites in the region, and improve tourist reception services, such as vehicle pick-up, accommodation reservation, etc.

\section{3) Improving the foreign language service system of} tourist attractions

In order to ease international tourists' language obstacles while on the road, the locality should provide standardized English training courses for the tour guides, rural cadres, and even the villagers. Equip the reception staff and tour guides with the ability to communicate and interact with foreign tourists, and finally provide the interpretation service for the tourist attractions. Receptionists and tour guides should also take the initiative to understand the culture and customs of foreign tourists when communicating with them. The purpose is to improve the quality and efficiency of services and avoid "cultural shock" [8]. And strive to improve the ideological and 
moral cultivation and communication skills of local villagers, improve the overall atmosphere of the village, and reduce the discomfort of tourists. At the same time, through the promotion of Facebook, YouTube, Twitter or other international social media, uploading photographs or English travel videos and other means for international communication, in order to promote the international popularity of Guangxi tourism.

It must be noted that the construction of tourist service will also bring economic benefit to the localalities as well. Take the Water-Sprinkling Festival for example. Although its original intention is not to develop tourism, but to wash away bad luck during the year, it still attracts a large number of travellers during the festival. So appropriate guidance and utilization of the government or civil organizations will greatly promote the local tourism development [9].

\section{4) Promoting through social networks}

Today's mobile Internet era, the emerging WeChat public account is more able to cater to the information needs of contemporary people than traditional website propaganda. The convenience of mobile phones enables the WeChat public account to disseminate information more efficiently. So, is it useful to use Wechat public account to promote the Guangxi folk eco-tourism festivals? The answer is unquestionable. After all, Wechat has become a business card in China.

By creating a WeChat public number to publish the festivals' bilingual propaganda tweets, uploading bilingual propaganda videos and improving the specific information of the festivals, the connotation and value of the Guangxi folk eco-tourism festivals will be accurately reproduced. As for the special geographical location of some characteristic villages, we will find out the geographical location of the villages and formulate the optimal tourism route, so that no matter domestic tourists or international friends, they can get to know these festivals in detail through public accounts, and no longer need to spend a lot of time and effort to find relevant information about festivals

In the tourist section of WeChat public account, we regularly update the enjoy ourselves with feasting and other kinds of entertainment, as well as interviews with tourists, and introduce festivals from the perspective of tourists, so that more tourists can understand the real folk eco-tourism. It also provides information on the hotel and the scenic spot tickets and gives certain discounts to domestic students and foreign students

\section{CONCLUSION}

Gan Lin, director of Gansu Tourism Bureau, once said, "By waking up a large number of cultural heritages from its primitive state, and making them tourist products that cater for tourists' tastes, we can integrate all aspects of cultural elements fully into modern tourism, making tourism more attractive [9].” Her words can also be applied to the promotion of Guangxi tourism.

Although there are still various problems in the current folk eco-tourism festivals in Guangxi, these problems will be solved in the future. At this stage, combined with appropriate translation and re-creation, and through a variety of domestic and international social media for wide initial dissemination, more potential foreign tourists can understand the folk customs of Guangxi and its folk eco-tourism festivals. The strong interest in tourism in Guangxi folk festivals will promote the international development of Guangxi tourism and transmission of Guangxi image.

\section{REFERENCES}

[1] M. Liu, G. Pan, R. Zhang, X. Fang, Y. Yang. A Study on the New Model of Folk Eco-tourism-A Case Study of the Development of Folk Culture Industry in Southwestern Guizhou. New Economy. 2015 (17). (In Chinese)

[2] Y. Xi. In-depth development of Guilin Gongcheng Peach Blossom Festivals. Coastal Enterprises and Science \& Technology. 2010 (1), pp. 91-94. (In Chinese)

[3] Q. He. The Development Mode Research of Guilin Folk Tourism Resource. Doctoral dissertation, Guangxi Normal University. 2008. (In Chinese)

[4] F. He Guangxi Folk Sports Tourism Resource Development and Protection Research --In Binyang Dragon Festivals as an Example. Doctoral dissertation, Guangxi University for Nationalities. 2014. (In Chinese)

[5] Y. Xi. In-depth development of Guilin Gongcheng Peach Blossom Festivals. Coastal Enterprises and Science \& Technology. 2010 (1), pp. 91-94. (In Chinese)

[6] Y. Xi. Visitor's Behavior Research and Application on Tourism Festivals in Ethnical County-A Case Study of the 7th Guilin Gongcheng Peach Blossom Festivals. Journal of Guangxi Normal University for Nationalities, 2009(2), pp.30-33. (In Chinese)

[7] Z. Wang, J. Han. Research on the Strategy and Path of Hunan Cultural Industry's International Communication and Promotion. Journal of Hunan Administration Institute. 2016 (6). (In Chinese)

[8] X. Dong. A study on the International Publicity Problems and Strategies of Shanxi Cultural Tourism. Social Sciences Journal of Universities in Shanxi, 2018(11), pp. 99-102+107. (In Chinese)

[9] L. Gan. Promote the integration of culture and tourism to a new level. Guangming Daily, 2018-12-11(005).

[10] J. Ding, H. Peng. A Study on the Influential Factors and the Exploitation Patterns to the Exploitation of National Tourism. Journal of SouthCentral University for Nationalities (Humanities and Social Sciences) 2002 (02), pp. 98-101. (In Chinese) 